\title{
Assessment of Water Quality of Okomu Wetland Using Water Quality Index
}

\author{
Ehiorobo S. I. ${ }^{1, *}$ and Ogbeibu A. E. ${ }^{2}$ \\ ${ }^{1,2}$ Department of Animal and Environmental Biology, Faculty of Life Sciences, University of Benin, Benin City, \\ Nigeria \\ Corresponding Author: *ehiorobostella@gmail.com
}

https://doi.org/10.36263/nijest. 2020.02.0224

\begin{abstract}
The water quality of the Okomu Wetland was evaluated using the Water Quality Index (WQI) technique which provides a number that expresses overall water quality of a water body or water sample at a particular time. Sampling of physicochemical parameters spanned two years covering the wet and dry seasons and the water quality data were obtained from 10 sampling locations; Ponds 36, 52, 54, 61, 64, 90, 94, Arhakhuan Stream, Okomu River (Agekpukpu) and Okomu River (Iron bridge) all within the Okomu National Park. Parameters such as Total Dissolved Solids (TDS), Turbidity, $\mathrm{pH}$, Electrical conductivity (EC), Chlorine (Cl), Nitrate $\left(\mathrm{NO}_{3}\right)$, Sulphate $\left(\mathrm{SO}_{4}\right)$, Sodium ( $\mathrm{Na}$ ), Magnesium (Mg), (Iron) Fe, Chromium (Cr), Zinc ( $\mathrm{Zn}$ ), Copper (Cu), Manganese $(\mathrm{Mn})$, Lead (Pb), and Nikel (Ni) were used to compute WQI and the values obtained for the wetland ranged between 34.36 and 167.28. The Index shows that pond 36, 52 and 54 are unfit for drinking with values between 103.86 and 167.28; ponds 61 and 64 are of the very poor quality category with WQI values of 95.19 and 92.44 respectively, Pond 90, pond 94, Arhakhuan Stream and Okomu River (Agekpukpu) are of poor quality and WQI values between and 53.58 and 73.15. Whereas, the Okomu River (Iron bridge) is within the good water quality (34.36) category. The Okomu River by Iron bridge is of good quality rating while other sampled points were of poor, very poor or unfit for drinking though these water bodies are mostly free from anthropogenic activities because of the conservative status of the study area. A major source of pollution within the wetland is surface runoff. The water quality of the wetland may not be suitable for man's consumption especially pond water which are majorly impacted by runoff, yet very important for the survival and sustenance of the forest animals and plants. The water quality index (WQI) interprets physicochemical characteristics of water by providing a value which expresses the overall water quality and thus, reveals possible pollution problems of a water body. It turns complex water quality data into information that is easily understandable and usable by scientists, researchers and the general public.
\end{abstract}

Keywords: Water Quality Index, Ponds, Stream, River, Wetland, Physicochemical parameters

\subsection{Introduction}

Water quality may be assessed based on physicochemical properties of water (Venkatesharaju et al., 2010, WHO, 2012; Ukenye and Taiwo, 2019). Water is vital for all life processes and results in ecosystems which include springs, lakes, rivers, wetlands and other aquatic ecosystems (WHO, 2000; Ukenye and Taiwo 2019). Among these ecosystems, wetlands are exceptional having high biodiversity and offer a wide range of ecosystem services including providing habitat for many endangered species, conservation of biodiversity, aquifer discharge and flood control, fish and food production, carbon storage (Barbier et al., 1997; Uluocha and Okeke, 2004; MEA, 2005; Asibor, 2009).

Wetlands are important components of Nigeria's watershed systems (Uluocha and Okeke, 2004; Asibor, 2009). Many wetlands even the large ones are seasonal (Gopal, 2015). They are the only ecosystems with international convention (Turner et al., 2000) and they gave rise to the first modern global nature conservation convention (Matthews, 1993). Studies on wetlands even though they are 
among the most productive ecosystems in the world have received minimal attention largely because they are considered "wastelands" (MEA, 2005) especially in developing countries. Benefits provided by wetlands are quite enormous, with increased importance worldwide, hence the need to protect the remaining wetlands (Millenium Ecosystem Assessment, 2005).

Protected areas such as National Parks are meant to conserve natural resources. Particularly in Nigeria, seven (7) protected areas have been identified including the Okomu National Park, although trespasses have been reported (Aremu et al., 2012; Olaleru and Egonmwan, 2014). The Okomu National Park formerly known as the Okomu Forest Reserve is rich and unique in its biodiversity and provides habitat to many endangered species including mammals, birds, amphibians and insects amongst others (Oates, 1995; Ogbeibu and Egborge, 1995; Aremu et al., 2012). It was of great conservation concern because of threatening deforestation through commercial logging, large scale plantation agriculture and communal farming (Ogbeibu and Victor, 1995). The present study aims at providing a simple interpretation of the water quality of the Okomu wetland using the water quality index (WQI).

\subsection{Methodology}

\subsection{Study area and sampling}

The Okomu Forest Reserve has an area of $1082 \mathrm{~km}^{2}$ and is in the lowland tropical rainforest $\left(6.5^{\circ} \mathrm{N}\right.$; $5.8^{\circ} \mathrm{E}$ ), about $75 \mathrm{~km}$ West of Benin City. It is situated between the Rivers Osse and Siluko. Edo State, Nigeria (Ogbeibu and Egborge, 1995; Ajayi, 2001). Sampling stations designated for the study comprised seven (7) temporary ponds, the Arhakhuan Stream, and Okomu River (at Agekpukpu and Iron bridge) as shown in Figure 1. Sampling stations were selected based on easy accessibility. The sampling was carried out monthly between January 2017 and December 2018, covering the rainy and dry season months.

\subsection{Physicochemical parameters analysis}

Temperature, $\mathrm{pH}$ and conductivity of the samples were measured in situ. The turbidity value in NTU (Nephelometric Turbidity Units) of water samples was determined using the turbidity meter, spectronic 2ID spectrophotometer at room temperature. Chloride was determined by Mohr's method, nitrate was determined using spectronic 2ID spectrophotometer and all other physicochemical parameters of the water samples were determined by standard methods (APHA, 1998) in the laboratory. Heavy metals were determined by using Atomic Absorption Spectrophotometer.

\subsection{Statistical analysis}

The Water Quality Index (WQI) was used to interpret the physicochemical characteristics of the Okomu wetland. The Water Quality Index (WQI) provides a value which expresses the overall water quality at a certain location and time using physicochemical parameters thereby, turning complex water quality data into information that is easily understandable and usable by scientists, researchers and the general public. It also reveals possible problems of pollution in a water body (Bharti and Katyal, 2011; Akoteyon et al., 2011; Jagadeeswari and Ramesh, 2012; Oboh and Egun, 2017, Ogbeibu and Ogiesoba-Eguakun, 2019).

Mean values were computed to characterize the physicochemical parameters of sampled stations and the water quality index (WQI) computed using Microsoft Excel (2013 version). WQI reduces the bulk of data into a single value and expresses the data in a simplified logical form which demonstrates annual cycles, spatial and temporal variations and trends in water quality (Shweta et al., 2013). The maximum permissible value of WQI is 100 , thus values greater than 100 indicate pollution and therefore unfit for man's consumption (Mohammad and Amba, 2018). Table 1 shows the weighted arithmetic water quality index ratings. The weighted arithmetic water quality index has been used by other researchers (Sajitha and Vijayamma, 2016, Ogbeibu and Ogiesoba-Eguakun, 2019; Rawlings and Ikediashi, 2020). 


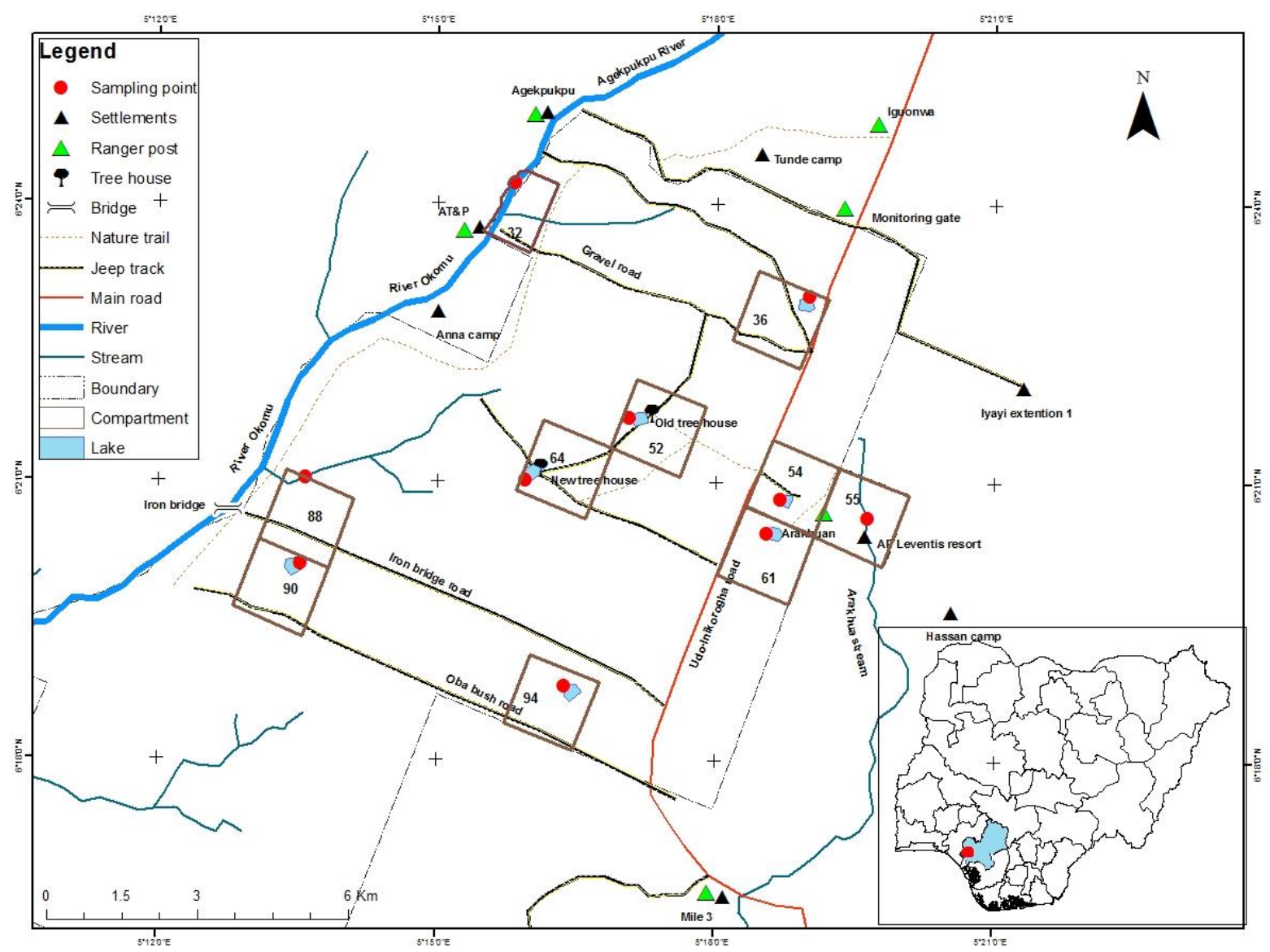

Figure 1: Map showing sampling stations in the study area, Okomu, Benin City, Edo State, Nigeria

The WQI was computed using the formula below:

$W Q I=\frac{\sum \mathrm{Q}_{i} W_{I}}{\sum \mathrm{W}_{i}}$

The quality rating scale $\left(Q_{i}\right)$ for each of the parameter analysed was computed using:

$\mathrm{Q}_{i}=100 \frac{\mathrm{V}_{i}-\mathrm{V}_{0}}{\mathrm{~S}_{i}-\mathrm{V}_{0}}$

where,

$V_{i} \quad$ Estimated concentration of the $i^{\text {th }}$ parameter of interest in the analysed water.

$V_{o} \quad$ Ideal value of the $i^{\text {th }}$ parameter in pure water. $V_{o}=0$ (Note; $\mathrm{pH}=7.0$ and $\mathrm{DO}=14.6$ $\mathrm{mg} / \mathrm{l})$

$S_{i} \quad$ Recommended standard value of the $i^{\text {th }}$ parameter

The unit weight $\left(W_{i}\right)$ is calculated using:

$W Q I=\frac{K}{\mathrm{~S}_{i}}$

$K=$ proportionality constant obtained using the equation below:

$K=\frac{1}{\sum \frac{1}{S_{i}}}$ 
Table 1: The weighted arithmetic Water Quality Index Ratings (Egun and Ogiesoba-Eguakun, 2018)

\begin{tabular}{|l|l|}
\hline Range & Rating of Water Quality \\
\hline $0-25$ & Excellent \\
\hline $26-50$ & Good \\
\hline $51-75$ & Poor \\
\hline $76-100$ & Very poor \\
\hline$>100$ & Unfit for drinking \\
\hline
\end{tabular}

\subsection{Results and Discussion}

From the data obtained, the mean values of the sampled stations (Table 2) and water quality index (Table 3) was calculated to quantify overall water quality status of water bodies of the area using the physicochemical conditions of the water. WQI is calculated according to the suitability of surface water for human consumption. The WQI for the studied water bodies is shown in Table 3 and Figure 2. Parameters such as water temperature, TDS, turbidity, $\mathrm{pH}, \mathrm{EC}, \mathrm{Cl}, \mathrm{NO}_{3}, \mathrm{SO}_{4}, \mathrm{Na}, \mathrm{Mg}, \mathrm{Fe}, \mathrm{Cr}, \mathrm{Zn}$, $\mathrm{Cu}, \mathrm{Mn}, \mathrm{Pb}, \mathrm{Ni}$ were considered. The computed values were compared with the WQI ratings for rational interpretations. Most parameters where within acceptable limits except for $\mathrm{pH}$, turbidity and Fe. $\mathrm{pH}$ of the area is acidic this is in agreement with the findings of Ogbeibu and Victor (1995), Jones (1955) for the then Okomu Forest Reserve, the low pH of the study area could be as a result of macrophyte growth which shades the water and thereby reducing photosynthetic activities. Reduced $\mathrm{pH}$ values have been associated with the growth of macrophytes (Kikuchi et al., 1976; Ogbeibu and Victor, 1995). Low pH has effect on water taste and appearance (Ogbeibu and Ogiesoba-Eguakun, 2019). The high turbidity values recorded is as a result of runoff. Higher turbidity values were recorded in Ponds than Stream and River. Dissolved oxygen was generally low this agrees with the findings of Ogbeibu and Victor (1995). They attributed the oxygen concentrations in most ponds to dense vegetation cover which affects oxygen diffusion and also, high oxygen demand by microorganisms during the oxidation of dead drowned macrophytes and other organic debris usually facilitated by the reduced pond volume and increased temperature especially in the dry season.

The Water Quality index for ponds 36, 52, 54, 61, 64, 90, 94, Arhakhuan Stream, Okomu River (Agekpukpu River) and Okomu River (Iron bridge) is given as 113.23 (unfit), 103.86 (unfit), 167.28 (unfit), 95.19 (very poor), 92.44 (very poor), 73.15 (poor), 75.51 (poor), 64.71 (poor), 53.58 (poor) and 34.36 (good) respectively. Pond 36, Pond 52 and Pond 54 were unfit for drinking, with Pond 54 being the poorest in this category while Pond 61, 64 are of very poor quality; 90, 94, Arhakhuan Stream and Okomu River (Agekpukpu) are of poor quality. Okomu River (Iron Bridge) falls within the good water quality category. The drinkable quality (best to worse) of the study area is in the order; Okomu River (Iron bridge) > Okomu River (Agekpukpu River) > Arhakhuan Stream > Pond $90>$ Pond 94 > Pond $64>$ Pond $61>$ Pond $52>$ Pond $36>$ Pond 54.

The Water Quality Index aggregates various parameters and their dimensions into a single score and then displays a picture of the water quality (Sajitha and Vijayamma, 2016). The water quality index of ponds sampled is in the range of 73.15 - 167.28; the ponds could have been impacted by run-off. The Arhakhuan Stream is of poor water quality probably because it is never devoid of human activities as the camp site is situated within the same compartment as the stream. The Okomu National Park visitors and tourist use the water most often to bathe, wash and other purposes. Another possible factor impacting the stream water quality is topography. The stream is located down a hill and receives runoff especially in the rainy season. The Agekpukpu River is also very accessible and has people including park rangers living around. Minor fishing activities sometimes take place in the Agekpukpu River. Water Quality Index of the Okomu River belongs to good category (26 - 50) and can be said to be suitable for drinking/domestic purposes. 
Table 2: Mean values of Physicochemical Parameters in the Study Area (Okomu National Park, Edo State, Nigeria) 2017-2018

\begin{tabular}{|c|c|c|c|c|c|c|c|c|c|c|c|c|}
\hline Parameters & Pond 36 & Pond 52 & Pond 54 & Pond 61 & Pond 64 & Pond 90 & Pond 94 & $\begin{array}{l}\text { Arhakhuan } \\
\text { Stream }\end{array}$ & $\begin{array}{l}\text { Agekpukpu } \\
\text { River }\end{array}$ & $\begin{array}{l}\text { Okomu } \\
\text { River }\end{array}$ & $\begin{array}{l}\text { FMEnv. } \\
1999\end{array}$ & $\begin{array}{l}\text { WHO, } \\
2011\end{array}$ \\
\hline Water temperature $\left({ }^{0} \mathrm{C}\right)$ & 25.20 & 26.70 & 24.1 & 25.41 & 24.14 & 25.75 & 27.0 & 22.92 & 28.67 & 27.6 & & \\
\hline TDS (mg/l) & 41.54 & 45.5 & 59.81 & 60.7 & 43.37 & 46.34 & 41.39 & 37.93 & 36.17 & 41.3 & 500 & 500 \\
\hline Turbidity(NTU) & 5.34 & 7.25 & 7.99 & 6.60 & 9.46 & 6.26 & 8.96 & 1.21 & 0.72 & 1.38 & 5 & 5 \\
\hline $\mathrm{EC}(\mu \mathrm{S} / \mathrm{cm})$ & 85.40 & 95.00 & 119.80 & 123.10 & 92.56 & 106.46 & 92.40 & 78.50 & 80.58 & 86.90 & & \\
\hline $\mathrm{pH}$ & 5.40 & 5.20 & 5.50 & 5.60 & 6.30 & 5.30 & 6.20 & 5.30 & 5.30 & 5.20 & $6.5-8.5$ & $6.5-8.5$ \\
\hline $\mathrm{DO}(\mathrm{mg} / \mathrm{l})$ & 1.91 & 1.93 & 2.80 & 3.00 & 2.50 & 2.44 & 2.45 & 1.54 & 2.13 & 2.68 & 7.5 & \\
\hline $\mathrm{Cl}(\mathrm{mg} / \mathrm{l})$ & 108.40 & 114.60 & 127.10 & 133.40 & 125.03 & 148.08 & 124.70 & 85.50 & 109.00 & 120.13 & 250 & $200-600$ \\
\hline $\mathrm{NO}_{2}(\mathrm{mg} / \mathrm{l})$ & 0.18 & 0.21 & 0.23 & 0.32 & 0.33 & 0.199 & 0.307 & 0.126 & 0.14 & 0.09 & 1.0 & 10 \\
\hline $\mathrm{NO}_{3}(\mathrm{mg} / \mathrm{l})$ & 0.78 & 0.95 & 0.96 & 1.39 & 1.36 & 0.95 & 1.27 & 0.55 & 0.58 & 0.48 & 10 & 50 \\
\hline $\mathrm{SO}_{4}(\mathrm{mg} / \mathrm{l})$ & 0.28 & 0.39 & 0.55 & 1.36 & 1.12 & 0.53 & 1.03 & 0.18 & 0.39 & 0.32 & $200-400$ & 200 \\
\hline $\mathrm{P}(\mathrm{mg} / \mathrm{l})$ & 0.42 & 0.78 & 1.004 & 4.30 & 1.13 & 0.88 & 1.04 & 0.29 & 0.27 & 0.35 & $<5$ & \\
\hline \multicolumn{13}{|l|}{$\left(\mathrm{x} 10^{-1}\right)$} \\
\hline $\mathrm{Fe}(\mathrm{mg} / \mathrm{l})$ & 8.7 & 11.3 & 17.5 & 10.9 & 11.0 & 8.1 & 8.1 & 6.8 & 6.7 & 6.5 & 1 & 0.3 \\
\hline $\mathrm{Cu}(\mathrm{mg} / \mathrm{l})$ & 0.51 & 0.07 & 0.1 & 0.07 & 0.07 & 0.040 & 0.04 & 0.034 & 0.02 & 0.02 & 0.1 & $0.05-1.5$ \\
\hline $\mathrm{Zn}(\mathrm{mg} / \mathrm{l})$ & 2.41 & 3.9 & 4.42 & 2.70 & 2.81 & 1.93 & 1.93 & 1.25 & 1.11 & 0.93 & 5 & 5.0 \\
\hline $\mathrm{Pb}(\mathrm{mg} / \mathrm{l})$ & 0.17 & 0.15 & 0.24 & 0.14 & 0.13 & 0.11 & 0.11 & 0.10 & 0.08 & 0.05 & 0.05 & 0.01 \\
\hline $\mathrm{Cd}(\mathrm{mg} / \mathrm{l})$ & 0.08 & 0.08 & 0.14 & 0.08 & 0.10 & 0.05 & 0.05 & 0.05 & 0.03 & 0.01 & 0.01 & \\
\hline $\mathrm{Cr}(\mathrm{mg} / \mathrm{l})$ & 0.2 & 0.19 & 0.59 & 0.19 & 0.18 & 0.10 & 0.10 & 0.07 & 0.10 & 0.09 & 0.05 & \\
\hline
\end{tabular}

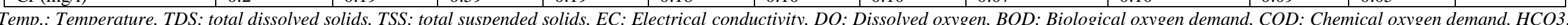

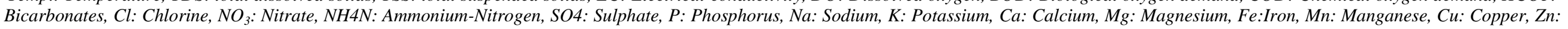
Zinc, Pb: Lead, Cd: Cadmium, Cr: Chromium, Ni: Nickel, V: Vanadium. 
Table 3: Water Quality Index of Study Stations in the Study Area (Okomu National Park), Edo State, Nigeria, 2017/2018

\begin{tabular}{|l|l|l|}
\hline Station & WQI & Category \\
\hline Pond 36 & 113.23 & Unfit for drinking \\
\hline Pond 52 & 103.86 & Unfit for drinking \\
\hline Pond 54 & 167.28 & Unfit for drinking \\
\hline Pond 61 & 95.19 & Very poor \\
\hline Pond 64 & 92.44 & Very poor \\
\hline Pond 90 & 73.15 & Poor \\
\hline Pond 94 & 75.51 & Poor \\
\hline Arhakhuan Stream & 64.71 & Poor \\
\hline Okomu River (Agekpukpu) & 53.58 & Poor \\
\hline Okomu River (Iron bridge) & 34.36 & Good \\
\hline
\end{tabular}

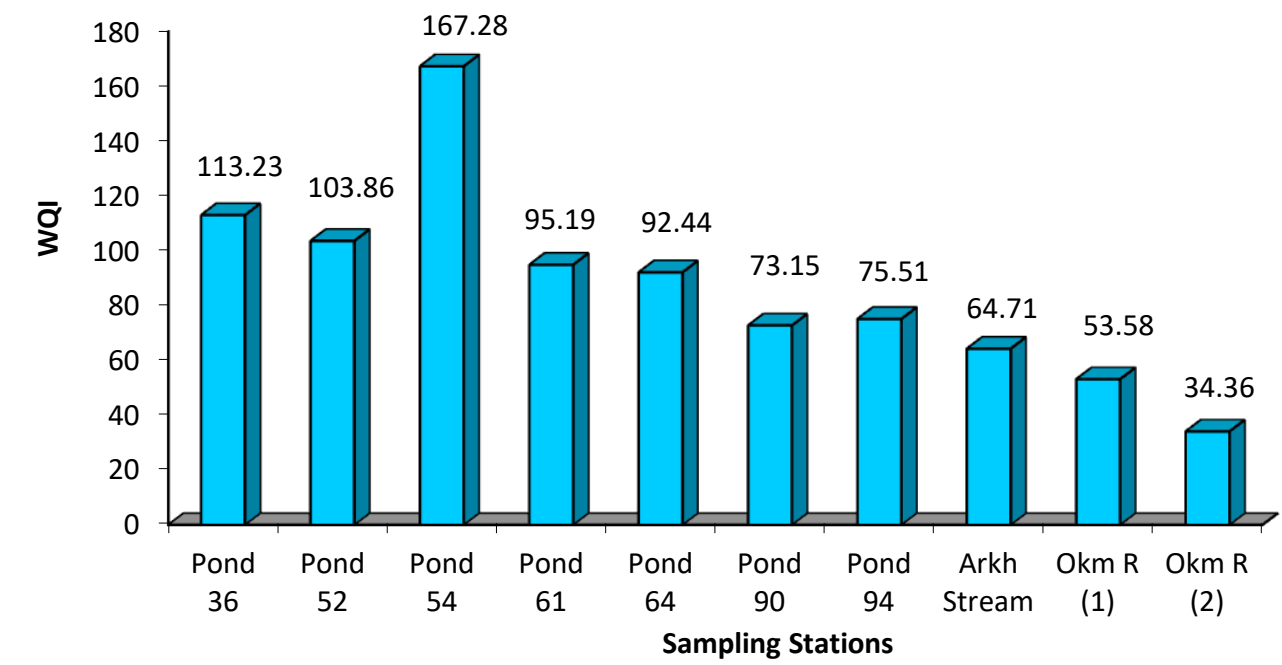

Arkh Stream: Arhakhuan Stream, Okm R (1): Okomu River (Agekpukpu), Okm R (2): Okomu River (Iron bridge)

Figure 2: Water Quality Index of the Study Area

The reason for the good water quality of the Okomu River at the sampled station just by the bridge, could be because the area is most of the time devoid of human activities due to crisis that sometimes occur between the surrounding communities and the park operators. The farmers and hunters claim to be owners of the land. It could also be as a result of its non- easy accessibility because of its distance from the camp site far away from park visitors. The river and its bridge serve as boundary between the National Park and surrounding communities. Sajitha and Vijayamma (2016) calculated the water quality index of Ponds in surrounding communities; Athiyannoor Panchayath, Kerala, India and the water quality indices (WQI) ranged between 6.47 and 16.17 indicating the excellent water quality. The values obtained in the present study are higher than that obtained in their studies whether for Pond, Stream or River. The lower the WQI value obtained the more suitable the water is for consumption.

\subsection{Conclusions}

The water quality of water bodies within the Okomu Wetland ranged between 34.36 and 167.28 which may not be suitable for man's consumption especially pond water which is majorly impacted by surface runoff yet, very important for the survival and sustenance of the forest fauna and flora. The water quality index (WQI) interprets the water quality of a system in a way that is easily understandable and usable by scientists, researchers and the general public. 


\section{References}

Ajayi, S. S. (2001). Multi-purpose forest management for bush meet production: A success story from West Africa. [online] Available at: http://www.fao.org. [Accessed on 27 Feb. 2017].

Akoteyon, I. S., Omotayo, A. O., Soladoye, O. and Olaoye, H. O. (2011). Determination of water quality index and suitability of urban river for municipal water supply in Lagos-Nigeria. Europ. $J$. Scientific Res, 54(2), pp. 263-271.

American Public Health Association /American Water Works Association/Water Pollution Control Federation (1998). Standard methods for the examination of water and waste water. 20th Ed. APHA, Washington, DC 1325pp.

Aremu, O. T., Emelue, G. U., Osayimwen, F. E. and Obasogie, F. O. (2012). Estimate of Habitat Quality of White- throated (Cercopithecus erythrogaster) in Okomu National Park, Nigeria. Nigerian Journal of Agriculture, Food and Environment, 8(1), pp. 47-51.

Asibor, G. (2009). Wetlands: values, uses and challenges. A Paper presented to the Nigerian Environmental Society at the Petroleum Training Institute, Effurun, $21^{\text {st }}$ November, 2009.

Barbier, E. B., Acreman, M. and Knowler, D. (1997). Economic Valuation of Wetlands, A Guide for Policy Makers and Planners Ramsar Convention Bureau, Gland, Switzerland.

Bharti, N. and Katyal, D. (2011). Water quality indices used for surface water vulnerability assessment. Int. J. Environ. Sci., 2(1), pp. 154 - 173.

Egun, N. K. and Ogiesoba-Eguakun, C. U. (2018). Physico-chemical and water quality index analysis of the Okhuaihe river, Edo State, Nigeria. African Journal of Aquatic Science, 43(4), pp. 345-351.

Gopal, B. (2015). Guidelines for Rapid Assessment of Biodiversity and Ecosystem Services of Wetlands, Version 1.0. Asia

Jagadeeswari, P. B. and Ramesh, K. (2012). Water Quality Index for Assessment of Water Quality in South Chennai Coastal Aquifer, Tamil Nadu, India. International Journal of Chem. Tech Research, 4(4), pp. $1582-1588$.

Jones, E. W. (1955). Ecological studies on the rainforest of southern Nigeria. IV. The Plateau Forest of the Okomu Forest Reserve. J. Ecol., 44, pp.564-594.

Kikuchi, E., Furusaka, C. and Kurihara, Y. (1976). Surveys of the fauna and flora in the water and soil of Paddy fields. The reports of the Inst. For Agric. Res. Tohoku Univ., 26, pp. 25 - 35.

Matthews, G. V. T. (1993). The Ramsar Convention on Wetlands: its history and development. In: Luthi E, Ramsar, editors. Gland (Switzerland): Ramsar Convention Bureau.

Millenium Ecosystem Assesment (2005). Ecosystems and Human WellBeing: Wetlands and Water Synthesis. World Recourses Institute, Washington, DC.

Mohammad, S. G. and Amba, S. (2018). Groundwater quality assessment of urban Bengaluru using multivariate statistical techniques. Applied Water Science, 8, pp. 43-56.

Oates, J. F. (1995). The dangers of conservation by rural development- A case study from the forests of Nigeria. Oryx, 29, pp. 115-122.

Oboh, I. P. and Egun, N. K. (2017). Utilization of Water Quality Index (WQI) in Water Quality Assessment of Groundwater in Agbor Metropolis, Delta State Nigeria. Int. Sci. Technol. J. Namibia 10, pp. $48-55$. 
Ogbeibu, A. E. and Egborge, A. B. M. (1995). Hydrobiological studies of water bodies in the Okomu Forest Reserve (Sanctuary) In Southern Nigeria. 1. Distribution and Diversity of the invertebrate fauna. Tropical Freshwater Biology, 4, pp. 1-27.

Ogbeibu, A. E. and Ogiesoba-Eguakun, C. U. (2019). Evaluation of water quality parameters of the Okhuaihe River, Edo State, Nigeria. Trop. Freshwat. Biol. 28(3), pp. 91-111

Ogbeibu, A. E. and Victor, R. (1995). Hyrobiological studies of water bodies in the Okomu Forest Reserve (Santuary) in Southern Nigeria. 2: physical and chemical hydrology. Tropical freshwater Biology, 4, pp. 83-100.

Olaleru, F. and Egonmwan, R. I. (2014). Wildlife Conservation Challenges in Okomu National Park, Nigeria. Ethiopian Journal of Environmental Studies and Management, 7(6), pp. 670 - 676.

Rawlings, A. and Ikediashi, A. I. (2020). Impact of urbanizing Ovia-North East on the quality of groundwater using water quality index. Nigerian Journal of Environmental Sciences and Technology, 4(1), pp. 87-96.

Sajitha, V. and Vijayamma, S. A. (2016). Study of Physicochemical Parameters and Pond Water Quality Assessment by using Water Quality Index at Athiyannoor Panchayath, Kerala, India. Emer Life Sci Res. 2(1), pp. 46-51.

Shweta, T., Bhavtosh, S., Prashant, S. and Rajendra, D. (2013). Water quality assessment in terms of water quality index. American Journal of Water Resources, 1, pp. 34-38.

Turner, R. K., van den Bergh, J. C. J. M., Söderqvist, T., Barendregt, A., van der Straaten, J., Maltby, E., and van Ierland, E. C. (2000) Ecological-economic analysis of wetlands: scientific integration for management and policy. Ecol. Econ. 35, pp. 7-23.

Ukenye, E. A. and Taiwo, I. A. (2019). Studies on the physicochemical status and biological characteristics of some rivers in Nigerian coastal states. International Journal of Fisheries and Aquatic Studies, 7(3), pp. 192-196.

Uluocha, N. and Okeke, I. (2004) Implications of wetlands degradation for water resources management: lessons from Nigeria. Geo. J. 61, pp. 151-151.

Venkatesharaju, K., Ravikumar, P., Somashekar, R. K. and Prakash, K. L. (2010). Physicochemical and bacteriological investigation on the river Cauvery of Kollegal stretch in Karnataka. Kathmandu University Journal of Science, Engineering and Technology, 6(1), pp. 50-59.

World Health Organization (WHO) (2000). Global Water Supply and Sanitation Assessment Report, Geneva.

World Health Organization (WHO) (2011). Water for Health, WHO Guidelines for Drinking-Water Quality. World Health Organization, Geneva.

World Health Organization (WHO) (2012). Guidelines for Drinking-water Quality, Fourth Edition, World Health Organization, Geneva.

Cite this article as:

Ehiorobo S. I. and Ogbeibu A. E., 2020. Assessment of Water Quality of Okomu Wetland Using Water Quality Index. Nigerian Journal of Environmental Sciences and Technology, 4(2), pp. 450-457. https://doi.org/10.36263/nijest.2020.02.0224 